Journal id: CMIT_A_506295

Corresponding author: Massimo Baioni

Title: Interpretations of Garibaldi in Fascist culture: a contested legacy 


\title{
Interpretations of Garibaldi in Fascist culture: a contested legacy
}

\author{
Massimo Baioni* \\ University of Siena, Italy
}

(Received 21 October 2009; final version accepted 8 February 2010)

Facing the controversial memory of the Risorgimento, Fascism was compelled to measure itself against Garibaldi, the nation's most celebrated and popular hero. The result was an exaltation of the alleged continuity between Redshirts and Blackshirts, marked by an emphasis on patriotic voluntarism that removed Garibaldi's adherence to the principles of liberty and democracy from his legacy. In the national discourse developed in the press and school textbooks, Garibaldi was harnessed to the ideological needs of the regime and held up as the embodiment of the Italian people's heroic militarism. However, as this article shows, the eclectic nature of fascist culture left room for more radical interpretations that did not fit the new official image of Garibaldi as a 'disciplined revolutionary'. Particularly among left-wing and younger fascists, Garibaldi became the precursor of the corporatist revolution, an icon of populism melding values of social transformation, moral intransigence and patriotic selfabnegation. This emphasis on the hero's radical legacy was to reappear glaringly between 1943 and 1945, when the civil war between fascists and partisans also became a battle over the symbols and memories of the Risorgimento.

Keywords: Garibaldi and fascism; fascist culture; Risorgimento; commemorations; Italian memory

What image of Garibaldi was current in Italy during the Fascist period, and what part did this play in the context of a more general reappraisal of the Risorgimento? How and when did Fascist culture operate to save the aspects of Garibaldi's political and military deeds that were best suited to modernisation? What links and differences were there between academic production and the field of public memory, which was entrusted to numerous media for popularisation, from school textbooks to the cinema, and from exhibitions to commemorative rituals? These are only some of the many complex and interconnected issues relating to the course of Garibaldian memory during the Fascist era. To study the main developments is to explore the ideological and cultural world of Fascism from a particular perspective, shedding light on the identity of the 'new' Fascist Italy through its relationship with both the Risorgimento tradition and its most popular figure.

The debate on the relationship between a Risorgimento past and the Fascist present was always intense, and its characteristics were mainly determined by the evolution of the regime, and by the choices made in both domestic and foreign policy. The high point for initiatives and ensuing public discussion regarding the comparison between the Risorgimento and Fascism was probably 1932. That year Italy celebrated in some style

\footnotetext{
*Email: maxbaioni@libero.it 
two key anniversaries: the fiftieth of the death of Garibaldi (2 June 1882) and the tenth of the March on Rome (28 October 1922). In relation to the memory of Garibaldi, this was the second important anniversary following the centenary of his birth in 1907. At that time, the commemorations took place during a period of open conflict between the Liberal government and opposition movements (notably, the Republicans and the Socialists). Twenty-five years later, with Fascism triumphant, the aim was to convey the image of a united nation achieving self-recognition with the full recruitment of Garibaldi to the Fascist colours.

Among the main initiatives, the regime launched the publication of Garibaldi's Opera Omnia and mounted a large exhibition on him in Rome's Palazzo delle Esposizioni. The event generating most public interest took place on 4 June, when the monument to Anita was unveiled on the Janiculum hill, exactly opposite the large statue of Garibaldi that had been erected in 1895. The official speech was given by Mussolini: in the presence of the King and Queen; he praised Anita as exemplary of the new Fascist woman. The weapon in her right fist represented the untamed courage and warrior spirit of Garibaldi's young wife, while the presence of her infant son Menotti, held in her left arm (a 'suggestion' that Mussolini had personally made to the sculptor Antonio Sciortino), emphasised her role as an attentive mother (Fogu 2003).

Mussolini underlined the 'right and responsibility' of Fascism to honour the memory of Garibaldi: present-day Italy was the product of participation in the First World War and of safeguarding its victory, both of which had been wanted and forced through by minorities acting in a Garibaldian 'spirit'. Mussolini concluded his speech as follows:

If by a miracle the bronze horseman who rears up near this spot were to come alive and open his eyes, I like to think that he would recognise the descendants of his Redshirts in the soldiers of Vittorio Veneto and the Blackshirts who for ten years have maintained, in an even more popular and productive manner, his volunteer spirit: and that he would be happy to rest his gaze on this vast, luminous and peaceful city of Rome, which he loved infinitely and from his early youth identified with Italy. (Mussolini 1932a, 111)

Here, the appropriation of the Garibaldian tradition by the regime reached its apex. The idea of the continuity between garibaldinismo and Fascism, and between Redshirts and Blackshirts, was promoted using all the media available for the production of history. Newspapers, textbooks, popular publications, commemorations, all built up the idea of a link between generations: across the centuries, ranks of heroes, artists and soldiers had kept alive the value of 'italianità', thus representing the 'unbroken continuity of our history, our triumphs, and our faith in both the past and the future'. ${ }^{1}$ The most crucial element of the meeting between garibaldinismo and Fascism was 'the essential element of the volunteer spirit', acknowledged as a 'tireless resource of the Italian nature'. At times of 'collective decadence' and 'crisis of authority', according to the Corriere della Sera, the volunteer ideal had provided the spur that had guided heroic minorities to trust in the 'instinctive generosity of the public spirit', thus restoring 'the most splendid uplifting energy' to the life of the nation. ${ }^{2}$

This interpretation had the authoritative support of one of Garibaldi's grandchildren, Ezio, who developed the idea of a 'Garibaldian Fascism' (Garibaldi 1928) and promoted this through the journal Camicia Rossa (Garibaldi and Fonterossi 1932). Other members of the family, by contrast, were more closely aligned with anti-Fascism (Ciuffoletti et al. 2005; Cecchinato 2009). A lively debate broke out within the culture of the regime itself: on several occasions Ezio Garibaldi had to defend his vision of the secular and inherent 
value of garibaldinismo, especially when the signing of the Lateran Pacts between Church and State in 1929 gave greater weight to Catholic culture and to its view of Italian history (Riccardi 1995; Malfitano 2007). There were many Fascist intellectuals (for example those writing for Vita Nova, the journal of the Fascist University of Bologna) for whom the connection with the memory of the Risorgimento and Garibaldi was seen primarily in terms of the development of modern secular thinking, resisting any concession to 'clericofascism' (Mangoni 1974; Tarquini 2009).

As these observations suggest, too simplistic an interpretation cannot re-create the full breadth and subtlety of the assimilation of Garibaldi and the Garibaldian tradition during the Fascist period. Such an interpretation needs to be situated within the wider frame of the politics of memory of the Risorgimento promoted by the regime - one intended to appear like a mirror in which the many aspects of Fascist culture are reflected. The construction of the totalitarian state, once opposition had been eliminated, was accompanied by increasing interest in both the relationship with intellectuals and the problems of cultural organisation (Turi 2002). The relationship with the past, and above all with the Risorgimento and the Great War, was crucial for the historical and political legitimisation of a regime among whose principal virtues was its claim to italianità (Woolf 1965; Zunino 1985).

105 The case of Garibaldi, moreover, raised several problems. First, there had to be reconciliation with a rich and diverse tradition, to whose development historians, journalists, scholars and poets had all contributed. In the realm of public memory every Italian city, starting in the 1880 s, had put up a monument to Garibaldi, often placed in symbolic symmetry with a statue dedicated to Victor Emmanuel II. This 'symbolic

110 diarchy', embodied in the icons of the 'democratic king' and the 'disciplined revolutionary' (Isnenghi 2007), was the product of a skilful commemorative and communicative strategy. Particularly in the age of Crispi (1887-1896), this responded to the need for a unifying, harmonious and reconciliatory image of the Risorgimento (Levra 1992). Protests against this 'normalisation' of Garibaldi were voiced by groups at the political extremes (Radicals, Republicans and later also Socialists), which fostered a public account opposing the official one, accompanying this with their own apparatus of symbols, rituals and liturgies (Riall 2007).

After Garibaldi's death, the movement which took its inspiration from him had sought, although with varying results, to gather together his legacy and take his ideals wherever 120 the opportunity to nourish their vitality presented itself (Cecchinato 2007). The sacrifice of his grandchildren Bruno and Costante, who in 1914 left to fight for France as volunteers and died at Argonne, revived the Garibaldian myth, which thus became a powerful weapon of propaganda in favour of Italian entry into the war in the spring of 1915.

125 Fascism had to enter this stream of conflicting traditions regarding Garibaldi's legacy, and adopt the aspects that most suited its own nature and objectives. Not surprisingly, in the more official demonstrations of public memory the image of the 'disciplined revolutionary' was employed. By this interpretation, Garibaldi was the patriot who at critical moments of national history (from the meeting at Teano in October 1860 to the

130 famous 'I obey' of 1866) had fought for the supreme objective of Italian unification, putting aside all other ambitions. Essentially, he had distinguished himself by his sense of discipline, respect for authority and recognition of the decisive role of the House of Savoy in consolidating the victories of the struggle for unification. 
Tailored to the new context of the totalitarian state, this 'reconciliatory' interpretation of Garibaldi circulated widely within the mass culture of Fascist Italy, especially in popular history and school textbooks (Lecco 1984; Soldani 1985; Scotto di Luzio 1996; Genovesi 2009). According to Alessandro Luzio, one of the most influential contemporary scholarly historians who had moderate pro-clerical leanings, the main quality of Garibaldi had been that of consistent faithfulness to "his long-held belief, at times of great national crisis, in pursuing the salvation of the country'. ${ }^{3}$ It could not be ignored that Garibaldi had extolled liberty and democracy in the fight against foreign despotism. This difficulty therefore had to be negotiated by minimising the importance of these values, and showing that they had always been secondary to the well-being of the nation. Only Fascism - says a publication commemorating the fiftieth anniversary of his death - could completely rescue Garibaldi, freeing him from the debates that had previously made him an object of wearisome controversy: 'Garibaldi's liberty did not mean the liberty of the individual, but the liberty of an Italian, the liberty to work for the patria and for the nation; it was his heroic quality that inspired dedication and sacrifice in even the most lowly' (Romagna garibaldina 1932).

150 Arrigo Solmi - respected historian and lawyer, and adherent of the thesis that Italians had aspired to unity for centuries - wrote that Garibaldi had been 'the bitterest enemy of factions and parties' (Solmi 1935, 293). Garibaldi's 'dictatorship' was interpreted, according to a view held widely at the time, in a similar manner: it was praised as the appropriate measure to confront the dangers faced by the patria. Solmi carefully avoided 155 recalling that the resort to dictatorship, although charged with different meanings before and after 1861 (Vetter 2003), had, however, been viewed by Garibaldi as a way of ruling on a temporary basis, and thus limited to wartime and the rapid resolution of the emergency situation that had prompted its adoption.

Fascism and Mussolini clearly felt compelled to assimilate the attractions of Garibaldi's epic story. Nevertheless, if applied in too direct a way, the lineage of patriotism raised numerous problems, relating back to the unstable link between Fascist culture and the Risorgimento. As Claudio Fogu (2003) has clearly shown, Mussolini gave close attention to preparations for the Garibaldi anniversary of 1932, checking the details of the ceremony for moving Anita's remains from Genoa to Rome. The risk was that the originality of Fascism might be compromised at the very moment when the regime, after the economic crisis of 1929 , was engaged in asserting its own identity with renewed vigour. Recognition of the link to garibaldinismo could not be allowed to obscure the equally strong need to mark out the particular characteristics of the new Fascist rituals, which had to restore the image of a regime striving daily to 'make' history and to re-establish the 170 distinguishing features of national identity.

The drive by Fascism to emphasise its own symbolic self-sufficiency, in order to free itself from too restrictive a relationship with the Risorgimento past, started with an appropriation of the memory of the Great War, whose legacy it claimed exclusively for itself (Gentile 1993). The dates of the declaration of war and its victorious conclusion, 17524 May and 4 November, were thus put alongside the 'sacred' anniversaries of the new rites: 23 March (1919, foundation of the Fascist groups), 21 April (foundation of Rome), and 28 October (1922, March on Rome and start of the so-called 'Fascist era'). In the many speeches given by Mussolini in the year of the tenth anniversary of the March on Rome, there was a recurrent emphasis on the significance of the new start represented by Italy's entry into the war. Speaking in Ancona, he defined 1915 as a 'fatal' year in world 
history, putting it alongside 476, 1492 and 1815 in importance: 'radiant May' became the point of no return, and the start of the 'real history of Italy', thanks to the transformation that finally led to the inclusion of the masses in the life of the national state (Mussolini 1932b, 157-58).

The card of the 'youthful' identity of Fascism was especially played on the table of ritual practice and symbolic language, during a time when the development of modern means of mass communication stimulated a marked enhancement of the various forms of the public use of history (Gallerano 1995). The Exhibition of the Fascist Revolution, inaugurated on 28 October 1932, was the most striking and ambitious setting for this vision of history, conveyed using display methods with a strong modernist aesthetic. It stayed open to the public for two years, with the number of visitors reaching four million. The Risorgimento and the first 50 years of unified Italy were left out of the chronological and thematic journey, which had contributions from the best-known Italian artists of the time. The representation of the link between Fascism and the history of Italy focused on the 1914-1922 period, and promoted the importance of the war as a moment of rupture in Italian history: the only element of the past that could be evoked as relating to the present was the drive of the 'heroic' interventionist minorities, foreshadowed by the Garibaldian volunteer spirit. In the exhibition halls, Mussolini and Fascism were in fact presented as the only legitimate heirs of the war experience and the 'men of the trenches'. Theirs was the credit for having defended the nation from the political and social turbulence of the 'biennio rosso' and from attacks by internal enemies, the former 'defeatists' now portrayed as a 'resurgent monster' in the hideous guise of bolshevism (Gentile 1993; Stone 1998; Schnapp 2003).

Many observed that the exhibition elicited strong emotional reactions and a degree of involvement that verged on the 'religious'. This came to a climax in the hall of the Fascist 'martyrs' who had died in the clashes of the early 1920s (Suzzi Valli 2008). Its symbolic value was yet more obvious when compared with the exhibition for the fiftieth anniversary of Garibaldi's death, which had taken place a few months earlier at the same venue, the Palazzo delle Esposizioni, and had enjoyed great public success. However, some critics, including Margherita Sarfatti, felt that the traditionalist display style of the earlier exhibition, with no artistic experimentation, had prevented the very fertile Garibaldi story from being used to best effect, and the visitor was left with 'a feeling of stupefaction and melancholy'. By contrast, the strength of the Exhibition of the Fascist Revolution was in its dynamic union of art, sculpture and architecture, which created a dramatic and engaging representation of the war and Fascism (Sarfatti 1933; Fogu 2003).

The idea of exalting the recent origins of Fascism, presenting it as the most effective response to the European crisis of the postwar period, surfaced several times during the Fascist era. However, despite some notable successes, with the Exhibition of the Fascist Revolution at the forefront, such an interpretation of history never prevailed as the dominant model. The reasons for this are various: in part it was due to the political choices of the regime, which had an instant effect in the arena of the public use of history and its representation; in part it should be ascribed to the fact that the dynamic forces in Fascist culture were varied and could not be subjugated to one perspective that only looked at trends and expressions of a modernist type (from the Futurists to the Exhibition of the 225 Fascist Revolution) - or at least not without risk of serious distortions in interpretation (Luzzatto 1998). The wars that Italy fought from 1935 onwards necessitated the reclamation of the past in its entirety, from ancient Rome to the Risorgimento, to give 
strength and symbolic resonance to the imperialist policy of Fascism. Moreover, the link with the past was too strongly rooted in the historicist culture of the period, as the proponents of an 'unbroken continuity' of Italian history had long dominated in the universities, academies and cultural institutions. Nor should it be forgotten that the monarchy, even if overshadowed by the cult of the Duce, still had an important place in the hierarchy of national symbolism, and its public image was closely connected to the Risorgimento myth originating in the nineteenth century.

235 On the other hand, the most eloquent confirmation of the reabsorption of 'iconoclastic' historical views also comes from the Exhibition of the Fascist Revolution, which did not end after its spectacular version of 1932-1934. With its transformation into a permanent exhibition, the style of display underwent major changes, profoundly altering its original character. The second version was opened in 1937, together with the great Augustan Exhibition of Romanità, in the context of the solemn events staged for the two-thousandth anniversary of the emperor's birth (Salvatori 2003). This combination was no coincidence: celebrating the 'rebirth' of the empire after the victorious war in Ethiopia, Fascism was bringing the myth of romanità and its related monumentality back to the centre of public debate. It thus made this pivotal to a view of history based on the notion of the "civilising mission' of Italy, with the aim of legitimising current choices as the inevitable outcome of a 'destiny' inscribed in the life of the nation (Giardina and Vauchez 2000).

\section{Garibaldi the condottiero}

The process of militarising history and culture during the 1930s also profoundly affected the figure of Garibaldi. The idea of continuity between Redshirts and Blackshirts was joined by an interpretation that extolled Garibaldi as 'duce' and military strategist, making him the embodiment of the implacable warrior spirit of the Italian people. Fascism sought to wash away the disgrace of military defeats such as Lissa and Custoza in 1866, Dogali in 1887 and Adua in 1896. Their memory had weighed heavy and long on the national spirit, despite frequent attempts to represent them as 'glorious' defeats (Isnenghi 1997). Italy - according to the Corriere della Sera in 1932 - had passed from fighting for liberties during the period of the Risorgimento and Garibaldi, to fighting for greatness in the age of Mussolini. These were temporal segments of a historical process aimed at endorsing Italy as a beacon of world civilisation. 'Courage, action, and spirit of sacrifice' were the values embodied by small groups of volunteers - first the Redshirts, later the Blackshirts which had with their heroism taken on responsibility for the destiny of the nation. ${ }^{4}$

The image of Garibaldi best suited to the particular political circumstances and the historiographical trends of the time emphasised his military ability, courage and spirit of self-denial. During the 1920s, the study of history had been marked by considerable eclecticism, with a hybrid coexistence of old and new nationalisms. The situation changed radically with the new decade, in the wake of the consolidation of the regime and the much greater consensus guaranteed by the agreements with the Church. An ambitious project to reform the institutes of historical research developed into a statutory reorganisation with major repercussions, encouraging modernisation of the research system and simultaneously giving more bite to the presence of the State and its powers of control and coordination. In the field of Risorgimento studies the most influential position was held by Cesare Maria De Vecchi di Val Cismon, one of the four leaders ('quadrumviri') 
of the March on Rome and a prime exponent of monarchical and Catholic Fascism. His appointment as president of the Institute for the History of the Risorgimento and director of the Rassegna storica del Risorgimento was the outcome of a hard-fought competition - entirely within the varying nationalism of historiography at the time - for control of the organisation of historical institutes, a sector of considerable strategic importance. As well as De Vecchi, some of the most visible characters from the Fascist intelligentsia and cultural politics of the regime were involved in this struggle, including Giovanni Gentile, Gioacchino Volpe, Francesco Ercole and Pietro Fedele. Not 280 coincidentally, with the exception of Volpe, all of these men at different times led the Ministry for Public Instruction, which became the Ministry for National Education in 1929.

With De Vecchi, a 'Savoyard-Fascist' style of interpretation of the Risorgimento had considerable influence in both historiography and schools. This aimed at markedly reducing the importance of any reference to the French Revolution and other foreign influences. With evident difficulty, the origins of the Risorgimento were pushed back to the start of the eighteenth century (the 'Battle of Turin', 1706), thus identifying its exclusively Piedmontese background. In this perspective, Fascism became the natural host for exaltation of the State, military force and discipline, inherited from the models of imperial Rome and the Savoyard state (De Vecchi 1937; De Felice 1984; Baioni 2006).

It is hardly surprising that in this interpretation of the Risorgimento the figure of Garibaldi could only find a place if cleansed of his 'awkward' libertarian roots and his many calls to a democratically inspired interventionism; in the name of ancient ideals, this had always been readily converted into concrete action for national solidarity (in South

295 America before 1848, France in 1870 and 1914, and Greece in 1897). The Garibaldi that remained was half the man, calcified in his acts of heroism, patriotic impetus, military action and adhesion to the policy of unification driven forward by Piedmont. In short, he was Garibaldi the 'commander' ('condottiero'), and he appeared as this in the title of a weighty volume published in 1932 by the Ministry of War. According to the Corriere della Sera's review, this book showed that it was possible to resolve the 'arbitrary opposition' of 'classical military styles' and 'Garibaldian spirit'. The First World War had been the point of resolution. In the trenches all the threads 'in the infinitely varied unity of sacrifice and heroism' had been drawn together. On the one hand, the volunteerist elements had adapted to the needs of discipline; on the other, 'the dominant grey mechanism of modern

305 warfare' had taken 'light and vibrancy from the Garibaldian spirit of the Italian soldier'. Garibaldi thus became synonymous with the qualities of the Italian soldier at war and of the 'temperament of the Italian people in arms'.

Garibaldi's courage was an integral part of his italianità. This, in turn, had found in Garibaldi an exceptional vehicle for its promotion. A popular book series, whose title,

310 'La Centuria di ferro' ('The Iron Centurion'), was indicative of the militarist use of history prevailing at the end of the 1930s, dedicated lively biographies to 100 famous Italians, brought together under the category 'precursors' of Fascism (Pedio 2005). It is significant that the volume on Garibaldi was entrusted to a soldier, Colonel Luigi Susani. The figure of the hero was recalled with descriptions such as 'Soldier and Commander', the 'greatest

315 Italian commander of the nineteenth century', second only to Napoleon Bonaparte. 'While he may be known as a republican and Mazzinian', the author writes, Garibaldi's actions had been inspired by his faith in 'independence for the patria from the foreigner', recognising the 'fascio of national forces' as the only means of attaining this 
(Susani 1938: 11-12, 75). Having quoted from Mussolini's speech of 4 June 1932 at the unveiling of the monument to Anita, Susani turned Garibaldi into a link in the chain of imperial tradition:

With even greater pride, we add, his spirit would today rejoice because, largely thanks to glorious traditions, which take their inspiration from his name, passed from the Redshirt to the infantryman and on to the Blackshirt of the age of Mussolini, the imperial glories of the Caesars flourish again on the sacred hills of Rome. (Susani 1938, 113)

In the same series, 'daring and heroism', a sense of honour and of obedience, together with a warlike volunteer spirit, were the terms in which Giuseppe Galli, another soldier, portrayed Nino Bixio, Garibaldi's main deputy during the campaign of 1860. Alluding to the link between the exploits of Garibaldi and Fascist involvement in the Spanish Civil

330 War, the author emphasised that 'our people are always like this: they acted as heroes in 1849 and 1911, in 1859 and 1915, in 1860 and 1935, in 1866 and in Spain. The strong and pure Italian race is ever thus.' Even with his exuberant temperament, Bixio was the forerunner of the 'believe, obey, fight' of Mussolini, and of reverence for God and for patria (Galli 1940, 74).

\section{Radical interpretations: from left-wing Fascism to anti-Fascism}

While the militarised and disciplined aspect of the hero functioned well in meeting the needs of the regime's imperialist policy, it could not gain universal support. Fascist culture's own eclectic composition prevented a monolithic vision of Garibaldi. The regime praised its own historic achievement of having integrated the masses into the national

340 state, thereby completing the mission of the Risorgimento which had been betrayed by the despicable parliamentary 'Italietta' of Depretis and Giolitti. For Garibaldi and the Garibaldian tradition, it was a case of recovering anything that evoked contact with the people, or direct action disconnected from the scheming of diplomacy, including awkward events such as Aspromonte and Mentana. Fascism could not exclude this radical aspect of the Garibaldian imaginary, which had a firm hold in the various circles of the Italian Left. This was, moreover, a delicate operation given that, as previously stressed, required those values to be separated from the democratic roots and ideas about liberty for which Garibaldi had fought all his life.

However, in many radical areas of Fascist culture, particularly the 'Strapaese' literary movement and among the young more generally, Garibaldi was undoubtedly still the popular hero par excellence, often contrasted with the ice-cold Cavour who was too coloured by liberal ideals to be unconditionally enrolled among the noble forefathers of Fascist Italy (Mangoni 1974; Zunino 1985). Berto Ricci, the young founder of the journal L'Universale, challenged the 'vestiges of an Italy born in top hat and tails' for the right to commemorate Garibaldi $(1932,132)$. The 'Dictator' was claimed as a hero who belonged exclusively to the people and the young: a man who by nature, ideals and behaviour was totally at odds with the various incarnations of post-unification liberalism. Garibaldi was therefore the icon of a different Italy, a rebel who was intolerant of compromise and sought social renewal and, as such, an authentic precursor of popular Fascism. The Fascist revolution would have to draw on that repository of values in order not to fall back into mere conservatism or the 'trasformismo' that had been so characteristic of Italian history (Buchignani 1994). 
The film 1860 by Alessandro Blasetti, which came out in 1934 and was dedicated to the venture of 'I Mille', provides further testimony to the relationship between garibaldinismo and Fascism, marked by popular interpretation. In its most didactic passages, the film stresses the damage inflicted on the cause of independence and unification by the conflicts that arose between the various schools of thought and politics in the Risorgimento. Individual characters represent the quarrelsome supporters of Mazzini, the House of Savoy, the Neo-Guelphism of Vincenzo Gioberti and the federal autonomism of Carlo 370 Cattaneo, all guilty of ceding advantage to the 'foreigners': the latter, in fact, in an important scene, take all the seats on a train, benefiting from the arguments between the Italian passengers. Only Garibaldi, who is almost physically absent in the film but continually evoked, rises up as a dynamic figure and champion of unification. This is elevated to a supreme value, a goal attainable only if political divisions and factional claims are abandoned. In this way, portraying the Garibaldian deeds of 1860, the film alludes to the unifying role of Mussolini in the chaotic context of postwar Italy: 'The time for discussion is over', says the Neo-Guelph sympathiser, finally converted to the Garibaldian cause, 'the time for action has come. He has taught us this.' Moreover, Blasetti himself indicated that the most appropriate key to an understanding of the film was an analogy:

In brief, the film wants to be this: an evocation of the atmosphere of 1860 , which was similar in many ways to that of 1920-1922. Streams of idle chatter, a political Tower of Babel, and unawareness of the imminent ruin of any chance of the country coming together. Isolated groups of patriots and silent rebels, determined and committed to die, stand out, with faith in a Man who will marshal their forces and fatally attract others when he moves the current political reality from the field of discussion to that of action. (Gori 1983, 83)

Perhaps because it is not readily obvious from the plot, the idea of passing the baton from Redshirts to Blackshirts is made explicit in the final scene. In the feverish moments of victory at the Battle of Calatafimi, the young Sicilian protagonist embraces his wife and repeats several times, 'Garibaldi said that we have made Italy'. The camera lingers on the Italian flag, which acts as a patriotic medium for a jump in time. This introduces the final sequence: a line of ancient Garibaldian veterans is pictured giving the military salute to a parade of bold young Fascist Blackshirts.

This is one of Blasetti's very few concessions, perhaps the only one, to a more excessive nationalist rhetoric. The most important thing about the film is in fact its distance from official and educational accounts of the Risorgimento, which hinged on extolling the virtues of the monarchy, army and diplomacy. The approach of Blasetti, who used nonprofessional actors, emphasises the participation of the ordinary Sicilian people in the struggle for unification. It also lets the motivation for their support for the Garibaldian venture shine through as an instinctive Italian passion, but also a fervent hope for social deliverance. From this point of view, the film may have run counter to ideas that were widespread in left-wing Fascist circles, which sought the antecedents for Fascist economic and social policy inspired by corporatism in some tendencies within the Risorgimento (especially in Carlo Pisacane, on whose portrait the camera dwells pointedly at one moment in the film) (Parlato 2000; Santomassimo 2006). In the light of its social content and its stylistic character, which makes it a work that on several counts anticipates neo-realism, it is not surprising that Blasetti's film had wide circulation even after the Second World War. With the embarrassing finale removed, it was used in material for the parliamentary elections of 18 April 1948 by the Fronte Democratico Popolare, the alliance 
410 between the Communist Party and Socialist Party that adopted the figure of Garibaldi as its own symbol (Forgacs 2001).

While restricted to some minority sectors of Fascist culture, the 'heretical' Risorgimento was also appealed to in these same years by Italian anti-Fascist circles in exile. Obviously, these groups gave it meanings which served a different evaluation of national history and its impact on the political debate. The Spanish Civil War, in particular, was the arena in which a furious battle developed between two opposing visions of patriotic volunteerism, and within this between irreconcilable ways of connecting with the spirit of the Garibaldian tradition. From 1935 onwards, in the pages of Giustizia e Libertà, Carlo Rosselli urged people not to abandon the Risorgimento to a Fascist monopoly. His decision to enter the debate was prompted by the urgent need to counter a trend in the same movement, which sought to locate the struggle against Fascism within a field of thinking that extended beyond the nineteenth-century tradition. According to Rosselli, the Risorgimento for which Mazzini, Garibaldi, Cattaneo and Pisacane had all fought, admittedly with disagreements and internal differences, had kept its vitality intact: its rescue and use as a precious resource were essential for the legitimisation of antiFascism, and for its political struggle. It was necessary, in opposition to moderate and royalist ideas and to the authoritarian deformations of Fascism, to lay claim to continuity with a democratic and popular tradition, and with a patriotic volunteer spirit which had to be stripped of the many nationalist and warmongering encrustations that had disfigured the essence of the Risorgimento (Castelli 1997, 40-46).

The lesson of anti-Fascism in exile would not be lost. Some years later, as is well known, the period of civil war, between September 1943 and April 1945, provided new conditions for bringing the debate on the legacy of the Risorgimento back within Italy's borders. Garibaldi and garibaldinismo, which the official interpretation of the Fascist era had tried to absorb within their exclusive portrait of the Italian hero, symbol of courage and military skill, returned to the centre of a bitter political and symbolic contest. The battle between the Fascists of the Republic of Salo and the partisans of the Resistance also took in the memory of the Risorgimento, and Garibaldi, followed by Mazzini, was certainly the most contested figure, as a result of the many connotations his name continued to generate (Pavone 1991). The two interpretations shared their rejection of the classic image based on a harmonious reconciliation between Garibaldi and the House of Savoy. The hero returned as champion of the republican tradition of the Risorgimento. But this tradition was then viewed in opposing ways, which reflected other irremediable divisions over the idea of Italy, of the patria and of national identity.

445 In the propaganda from Salò, the aim was clearly to further delegitimise the monarchy, guilty of the 'betrayal' of 8 September, and to put forward the new regime as heir to the republican soul of the Risorgimento, in a desperate attempt to promote the social and popular nature of 'true' Fascism. Now destined for defeat and immersed in an atmosphere of cupio dissolvi (self-destruction), the Fascists portrayed themselves as the 'new' Garibaldini: they emphasised the purity and the spirit of sacrifice of those who, despite knowing themselves doomed, continued to strive to honour an ideal, did not retreat in the face of defeat, fought to their death and accepted 'martyrdom'. It was not by chance that one of the most frequent references was to Mentana, where in 1867 Garibaldi had had to give way to the military superiority of the French, who had rushed to the defence of the 455 Pope. The past was reinterpreted through the lens of duty and honour, the central concepts of republican Fascism's understanding of itself. Garibaldi had been a man who all his life 
had followed 'with mystical and religious steadfastness the spirit of duty and honour': this was how Santa milizia, the newspaper of the Fascist federation of Ravenna, remembered him on the anniversary of his death. It railed at the 'assortment of renegades and traitors' who had 'dared to give his name to the groups whose undertaking is to stab the Nation at war in the back'.

The intensity with which the Fascists tried to contest the way the partisans were using Garibaldi and the republican Risorgimento was, however, an indication of the fragility of their own position, in an environment which was progressively less susceptible to the influence of propaganda from Salò. In fact the image of the Resistance as a 'second Risorgimento', which emerged in the final months of the war, was destined for widespread recognition in the public memory of the new Italian democracy (Pavone 1995; Gentile 1997; Focardi 2005). Garibaldi was one of its main pillars, in the wake of the operation to reclaim the democratic and Garibaldian tradition which had been initiated in the mid-1930s and the Spanish Civil War by the anti-Fascist forces of the Left.

On 2 June 1946, the day of the referendum on the nature of the Italian state, it seemed as if the Italian republic wanted to put its trust symbolically in the favourable omens of the Garibaldian star. The birth of the new republican regime was timed to coincide with the anniversary of Garibaldi's death, a date pregnant with history and memories. Since the end of the nineteenth century, republican democratic circles had always entrusted an important part of their own legitimisation to this, making it a key point in their ritual and the promotion of their political culture.

\section{Conclusions}

The variety of positions which had in the past surrounded the memory of the

Risorgimento, and in particular within this the specific memory of garibaldinismo, did not disappear during the Fascist era. The advent of the dictatorship, eliminating any opposition, put the anti-Fascist interpretation of the Risorgimento and Garibaldi in confinement. But since Fascist ideology put down its roots into the restless ideological laboratory of the first 20 years of the century, a lively divergence in positions managed to survive as a phenomenon entirely within the culture of the regime, drawing into the present some reverberations from previous debates: from the reconciliatory version of the final two decades of the nineteenth century to the heterodox versions that came with the revisionist debate at the start of the twentieth. The comparison with the recent past thus generated contrasting views, which also referred to a different concept of what Fascism should represent in Italian history.

The most striking result was the co-option of Garibaldi to the ideological needs of the regime, which successfully insinuated itself into the hybrid legacy of garibaldinismo, laying claim to its concepts of order, discipline and authority (Isnenghi 1984). The implied continuity between Redshirts and Blackshirts gave popular content to the idea of Fascism as 'realisation' of the Risorgimento, initially developed by important intellectuals such as Giovanni Gentile and Gioacchino Volpe. However, the heterogeneous nature of the ideology and culture of fascism made the picture more blurred and dynamic, interweaving different perspectives on the supposed confluence of Garibaldi and the Risorgimento with contemporary Fascist Italy. 
Intolerance towards the moderate image of Garibaldi and the Savoyard interpretation of the Risorgimento, for example, was evident within the circles of Fascist radicalism, where the delicate issue was raised of the references to the past from which Fascism had to draw its energy for action in the present. For the intellectuals of the 'Strapaese' movement, from Curzio Malaparte to Mino Maccari, Garibaldi was one of the few Risorgimento figures who, because of his popular/populist aspect, had been re-inserted within a vision of national history that exalted the 'healthy' rural and premodern tradition, making this the essential basis for any claim on italianità. From this perspective, Fascism became an experience that did not simply refer back to the nineteenth-century tradition, whose profoundly liberal features could not be hidden in the long term. Even among those who saw the Risorgimento as an important symbolic resource for the present, there were those who preferred to rehabilitate figures who had fought for a concept of patria and nation different from what was actually created under the colours of the House of Savoy. Especially within youth culture, trade unionism and left-wing Fascism, men like Garibaldi, Mazzini, Pisacane and Cattaneo had their democratic baggage removed and were reduced to being supporters of a corporatist model ante litteram.

The difficulty encountered by Fascism in offering a version of the Risorgimento past unencumbered by tensions and conflicts re-created particular issues that had featured in the process of Italian unification, among them the complex operation of 'nationalisation of the outlying areas'. In fact, the system of the nineteenth-century tradition could count 520 on both the strength of the literary legacy of Giosue Carducci, always central to the channels of educational development, and the persistence of numerous forms of local identity. A rich and developed structure was at issue; it determined a patriotic 'geography' that Fascism had to reckon with. As has been noted, despite loud declarations against any drift away from the centre, at various points the regime tried to exploit the theme of 'piccole patrie', turning this towards serving the new national project. Popular celebrations and rituals linked to local folklore were in this way adapted for the new context (and sometimes they were even 'invented', an example being the 'festival of grapes'), especially when they derived from well-established peasant traditions (Cavazza 1997).

530 Moreover, in the field of Risorgimento studies and memory, some institutions that were only partially affected by Fascist revisions of national history continued their activities. Examples are the museums of the Risorgimento, which from the end of the nineteenth century had become popular places for the 'visual' narration of national history. The Fascist regime intervened here too: display objects relating to the Great War,

535 the March on Rome, and right up to the wars in Ethiopia and Spain, were added to those from the Wars of Independence. The idea of a 'long Risorgimento' was thus supposed to emerge from the exhibitions; this linked the achievement of unification with the arrival of a new imperial and Mediterranean order. In contrast to some which had undergone significant developments, many museums kept the structure from their original establishment, declining to apply the model of aesthetic modernisation introduced by the Exhibition of the Fascist Revolution (Baioni 1994, 2006). In the schema of their displays, the Great War was seen as the final stage of the Risorgimento and of national unity, a rather earlier origin of the new Italy than that desired by Fascism. The 'museum story' of the Risorgimento mostly continued to speak a nineteenth-century language, and the 545 Garibaldian tradition was allowed to connect national victories to pride in local heroism, underlining the harmony between grande patria and piccola patria. 
The controversial and complex matter of the fortunes of Garibaldi during the Fascist era thus serves as a very useful proving ground for understanding the departure from the nationalist interpretation and the repositioning of garibaldinismo within the constraints of the democratic tradition. The operation led by anti-Fascist groupings, and especially by the Partito d'Azione and the Communist Party during the Resistance, successfully entered a chaotic space that Fascism had not been able to occupy in a totalitarian way. When the regime started to collapse under the blows of military defeat, for those who sought to re-create an idea of patria that was not linked to a warmongering nationalism, the possibility emerged of looking afresh at the distant layers of memories, images and symbols of liberty: and the figure of Garibaldi could return to the centre of yet another recovery, as a popular icon legitimising the struggle for a new and more advanced democracy.

\section{Notes}

1. Corriere della Sera, 'Le spoglie di Anita nella pace gloriosa del Gianicolo', June 3, 1932.

2. Corriere della Sera, 'Garibaldi e l'Italia nuova', June 5, 1932.

3. A. Luzio, 'Garibaldi e Cavour,' Corriere della Sera, June 4, 1932.

4. Corriere della Sera, 'Garibaldi e l'Italia nuova', June 5, 1932.

5. A. Valori, 'Recensione a Garibaldi condottiero', Corriere della Sera, June 2, 1932.

6. M. Bertozzi, 'L'Eroe dei due mondi', La santa milizia, June 3, 1944.

\section{References}

Baioni, M. 1994. La 'religione della Patria'. Musei e istituti del culto risorgimentale (1884-1918). Treviso: Pagus.

Baioni, M. 2006. Risorgimento in camicia nera. Studi, istituzioni, musei nell'Italia fascista. Rome: Carocci.

Buchignani, P. 1994. Un fascismo impossibile. L'eresia di Berto Ricci nella cultura del Ventennio. Bologna: Il Mulino.

575 Castelli, A., ed. 1997. L'Unità d'Italia. Pro e contro il Risorgimento. Rome: Edizioni e/o.

Cavazza, S. 1997. Piccole patrie. Feste popolari tra regione e nazione durante il fascismo. Bologna: Il Mulino.

Cecchinato, E. 2007. Camicie rosse. I garibaldini dall'Unità alla Grande Guerra. Rome-Bari: Laterza.

Cecchinato, E. 2009. 'Fascismo garibaldino' e garibaldinismo antifascista. La camicia rossa tra le due guerre. Memoria e ricerca, 32: 113-36.

Ciuffoletti, Z., A. Colombo, and A. Garibaldi Jallet, eds. 2005. I Garibaldi dopo Garibaldi. La tradizione familiare e l'eredità politica. Manduria: Lacaita.

De Felice, R. 1984. Gli storici italiani sotto il regime fascista. In Federico Chabod e la "nuova storiografia' italiana dal primo al secondo dopoguerra (1919-1950), ed. B. Vigezzi, 559-618.

585 Milan: Jaca Book.

De Vecchi, C.M. 1937. Bonifica fascista della cultura. Verona: Mondadori.

Focardi, F. 2005. La guerra della memoria. La Resistenza nel dibattito politico italiano dal 1945 a oggi. Rome-Bari: Laterza. 
Fogu, C. 2003. The historic imaginary: Politics of history in fascist Italy. Toronto: University of Toronto Press.

Forgacs, D. 2001. Nostra patria: Revisions of the Risorgimento in the cinema, 1925-52. In Making and remaking Italy: The cultivation of national identity around the Risorgimento, ed. A.R. Ascoli and K. Von Henneberg, 257-76. Oxford: Berg.

Gallerano, N. ed. 1995. L'uso pubblico della storia. Milan: FrancoAngeli.

595 Galli, G. 1940. Nino Bixio. Milan: Oberdan Zucchi.

Garibaldi, E. 1928. Fascismo Garibaldino. Rome: Edizioni di 'Camicia Rossa'.

Garibaldi, E., and G. Fonterossi. 1932. Garibaldi nel cinquantenario della sua morte: 1882-1932. Rome: Camicia Rossa.

Genovesi, P. 2009. Il manuale di storia in Italia. Dal fascismo alla Repubblica. Milan: FrancoAngeli.

Gentile, E. 1993. Il culto del littorio. La sacralizzazione della politica nell'Italia fascista. Rome-Bari: Laterza.

Gentile, E. 1997. La Grande Italia. Ascesa e declino del mito della nazione nel ventesimo secolo. Milan: A. Mondadori.

Giardina, A., and A. Vauchez. 2000. Il mito di Roma. Da Carlo Magno a Mussolini. Rome-Bari: Laterza.

Gori, G.F. 1983. Dossier 1860. Storie e storia 9: 77-91.

Isnenghi, M. 1984. Usi politici di Garibaldi dall'interventismo al fascismo. In Garibaldi condottiero. Storia, teoria, prassi, ed. F. Mazzonis, 533-44. Milan: FrancoAngeli.

Isnenghi, M. 1997. Le gloriose disfatte. Mélanges de l'Ecole Française de Rome. Italie et Mediterranée 109, no. 1: 21-34.

Isnenghi, M. 2007. Garibaldi fu ferito. Storia e memoria di un rivoluzionario disciplinato. Rome: Donzelli.

Lecco, E. 1984. Garibaldi nella letteratura scolastica per l'infanzia durante il fascismo. In Garibaldi condottiero. Storia, teoria, prassi, ed. F. Mazzonis, 576-85. Milan: FrancoAngeli.

Levra, U. 1992. Fare gli italiani. Memoria e celebrazione del Risorgimento. Turin: Comitato di Torino dell'Istituto per la Storia del Risorgimento Italiano.

Luzzatto, S. 1998. La cultura politica dell'Italia fascista. Storica 12: 57-80.

Malfitano, A. 2007. La figura di Giuseppe Garibaldi nell'Italia fascista. Mussolini, Ezio Garibaldi e il 'fascismo garibaldino'. Storia e futuro 15. http://www.storiaefuturo.com

Mangoni, L. 1974. L'interventismo della cultura. Intellettuali e riviste del fascismo. Rome-Bari: Laterza.

Maturi, W. 1962. Interpretazioni del Risorgimento. Lezioni di storia della storiografia. Turin: Einaudi.

Mussolini, B. 1932a. Epopea garibaldina. In Opera Omnia di Benito Mussolini, ed. E. Susmel and D. Susmel, 108-11. Vol. XXV. Florence: La Fenice, 1958.

Mussolini, B. 1932b. Al popolo di Ancona. In Opera Omnia di Benito Mussolini, ed. E. Susmel and D. Susmel, 157-8. Vol. XXV. Florence: La Fenice, 1958.

Parlato, G. 2000. La sinistra fascista. Storia di un progetto mancato. Bologna: Il Mulino.

Pavone, C. 1991. Una guerra civile. Saggio storico sulla moralità nella Resistenza. Turin: Bollati Boringhieri.

630 Pavone, C. 1995. Le idee della Resistenza. Antifascisti e fascisti di fronte alla tradizione del Risorgimento. Alle origini della repubblica. Scritti su fascismo, antifascismo e continuita' dello stato. 3-69. Turin: Bollati Boringhieri.

Pedio, A. 2005. Le collane editoriali di storia. Da 'I prefascisti' a 'I grandi italiani'. Storiografia 9: 175-207.

635 Riall, L. 2007. Garibaldi. L'invenzione di un eroe, trans. David Scaffei. Rome-Bari: Laterza.

Riccardi, A. 1995. Il Risorgimento e la cultura cattolica durante il fascismo. Il Risorgimento 1-2: 359-68.

Ricci, B. 1932. Cinquantenario. Camicia Rossa 1: 132.

Romagna garibaldina. 1932. Ravenna: n. p. 
640 Salvatori, P. 2003. La seconda Mostra della Rivoluzione Fascista. Clio 3: 439-59.

Santomassimo, G. 2006. La terza via fascista. Il mito del corporativismo. Rome: Carocci.

Sarfatti, M. 1933. Architettura, arte e simbolo alla Mostra del Fascismo. Architettura 12: 1-17.

Schnapp, J.T. 2003. Anno X. La Mostra della Rivoluzione fascista del 1932. Pisa: Istituti editoriali poligrafici internazionali.

645 Scotto di Luzio, A. 1996. L'appropriazione imperfetta. Editori, biblioteche e libri per ragazzi durante il fascismo. Bologna: Il Mulino.

Soldani, S. 1985. Il Risorgimento a scuola: incertezze dello Stato e lenta formazione di un pubblico di lettori. In Alfredo Oriani e la cultura del suo tempo, ed. E. Dirani, 133-72. Ravenna: Longo.

Solmi, A. 1935. Giuseppe Garibaldi e l'Unità italiana (1932). In Discorsi sulla storia d'Italia, ed. A. Solmi, 288-317. Florence: La Nuova Italia.

Stone, M. 1998. The patron state: Culture and politics in Fascist Italy. Princeton, NJ: Princeton University Press.

Susani, L. 1938. Giuseppe Garibaldi. Milan: Oberdan Zucchi.

Suzzi Valli, E. 2008. Il culto dei martiri fascisti. In La morte per la patria. La celebrazione dei caduti dal Risorgimento alla Repubblica, ed. O. Janz and L. Klinkhammer, 101-17. Rome: Donzelli.

Tarquini, A. 2009. Il Gentile dei fascisti. Gentiliani e antigentiliani nel regime fascista. Bologna: Il Mulino.

Turi, G. 2002. Lo Stato educatore. Politica e intellettuali nell'Italia fascista. Rome-Bari: Laterza.

Vetter, C. 2003. Dittatura e rivoluzione nel Risorgimento italiano. Trieste: EUT.

660 Woolf, S.J. 1965. Risorgimento e fascismo. Il senso della continuità nella storiografia italiana. Belfagor 1: 71-91.

Zunino, P.G. 1985. L'ideologia del fascismo. Miti, credenze e valori nella stabilizzazione del regime. Bologna: Il Mulino. 